\title{
Nutrient Composition of Artocarpus champeden and Its Hybrid (Nanchem) in Negara Brunei Darussalam
}

\author{
L. B. L. LIM*, H. I. CHIENG AND F. L. WIMMER \\ Department of Chemistry, Faculty of Science, Universiti Brunei Darussalam, \\ Jalan Tungku Link, Gadong BE 1410, Brunei Darussalam
}

\begin{abstract}
The flesh and seeds of ripened and unripened Artocarpus champeden and its ripened hybrid (Nanchem) were analyzed for their moisture, ash, crude fibre, crude protein, crude fat, total carbohydrate, energy and mineral content. Generally, unripened A. champeden which is always treated and cooked as a vegetable contains higher amounts of moisture, ash, crude fibre and crude protein for its flesh than ripened A. champeden and Nanchem. Ripened A. champeden and Nanchem have higher total carbohydrates and energy content than the unripe fruit. Similarly, the unripened A. champeden seed has more nutritional components in terms of moisture, ash, crude fibre, crude protein, crude fat, total carbohydrate and energy compared to the ripened A. champeden and Nanchem seeds. Potassium and magnesium are the prevalent minerals in this fruit species. Nanchem has the characteristics of both jackfruit (A. heterophyllus) and A. champeden
\end{abstract}

Key words: Artocarpus champeden; Tibadak; Nanchem; ripened; unripened; moisture; crude fibre; crude protein; crude fat; total carbohydrate; energy; mineral content

Artocarpus champeden (Thunb.) Merr (syn Artocarpus integer Merr.) belongs to the Moraceae family. The name of the genus Artocarpus is derived from the Greek words artos which means bread and carpos which means fruit (Bailey 1942). A. champeden is in the same family as jackfruit (A. heterophyllus Lam.), breadfruit (A. altilis) and tarap (A. odoratissimus) (Janick \& Paull 2008; Subhadrabandhu 2001). The fruit of this genus is generally large (Figure 1).

A. champeden is traditionally grown in tropical and sub-tropical regions, particularly in Southeast Asia where it is widely distributed in southern Thailand, Peninsular Malaysia, Myanmar, Vietnam and Indonesia (Subhadrabandhu 2001). Consequently, it has various vernacular names depending on the country and language; such that in Thailand it is called 'Champada' and in Myanmar it is known as 'Sonekadat' (Janick \& Paull 2008; Jarrett 1960). In Brunei Darussalam, the fruit is locally known as either 'Tibadak' or 'Cempedak'.

The A. champeden fruit (Figure 1) can be consumed either ripe or unripe (mature or immature). Both the flesh and seed (Figure 2) of $A$. champeden are edible; the skin and core are inedible and are discarded as waste. The flesh is normally eaten fresh, deep fried into fritters, processed into a refreshing juice, dried into chips or creamed to make jams and cakes. Unripe A. champeden is always treated as a vegetable and cooked in coconut milk, eaten along with vegetables, or in soup: a common delicacy in Malaysia and south India (Janick \& Paull 2008; Subhadrabandhu 2001). The seed is either roasted or boiled in salty water; it is a popular delicacy amongst the Malayan jungle tribes (Janick \& Paull 2008; Subhadrabandhu 2001). Moreover, the seed can

\footnotetext{
* Corresponding author (e-mail: linda.lim@ubd.edu.bn)
} 


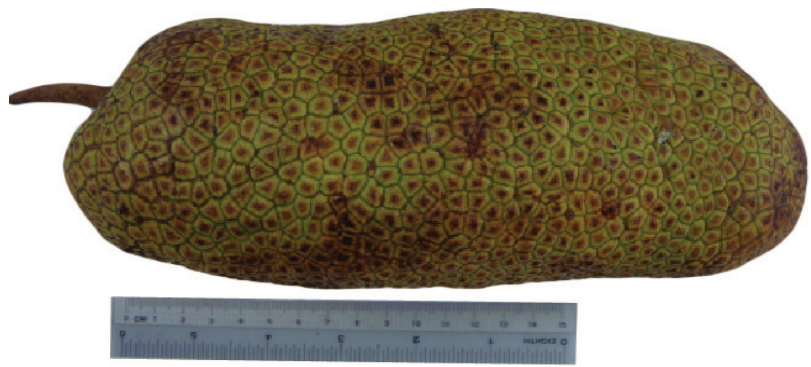

Figure 1. Artocarpus champeden fruit (Length:23 cm).
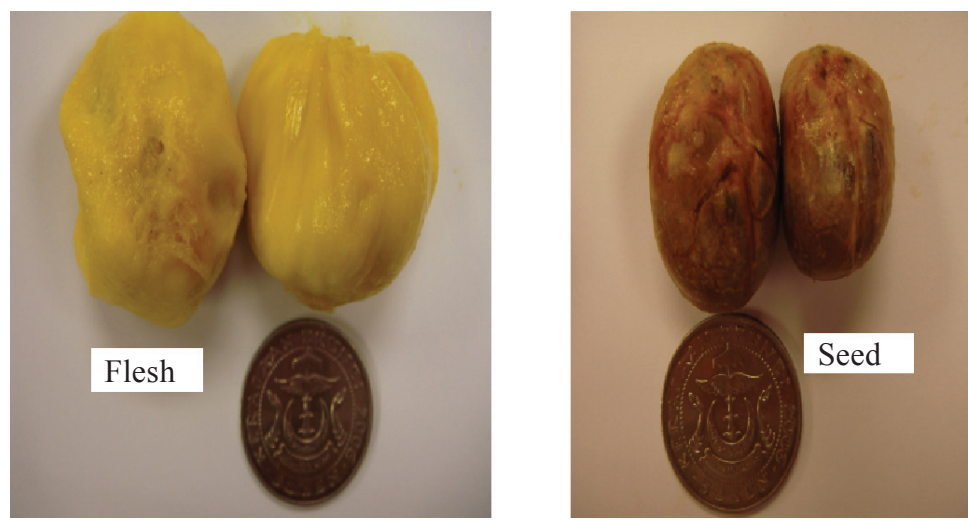

Figure 2. Artocarpus champeden flesh and seed with Brunei 50 cent coin (diameter: $28 \mathrm{~mm}$ ) for comparison.

be dried and ground to make flour for baking. A. champeden's seed flour provides a good source of dietary fibre and resistant starch (Zabidi \& Aziz 2009).

Research has shown that the skin of the $A$. champeden fruit can be used for the removal of methylene blue (Prahas et al. 2008) and cadmium(II) ions from aqueous solution (Inbaraj \& Sulochana 2004). On the other hand, the stem bark, aerial plant and roots have been reported to possess anti-malarial properties (Boonlaksiri et al. 2000) and cytotoxicity (Hakim et al. 2006; Hakim et al. 2005). A. champeden seeds contain lectins such as IgA1-reactive and ${ }_{D}$-galactose-binding lectin. These lectins have been found to be useful in biomedical research for the detection of tumors and the identification of glycoprotein (Lim et al. 1997).
A. champeden is commonly grown from the seed; with this method the tree would only bear fruit after five years. Grafting is another method that is widely used in agriculture where plant tissue such as the stem or bark are fused with another plant. With the success of this method, many variations of $A$. champeden can be found in the market nowadays. One such popular variation commonly found in Brunei Darussalam is its hybrid with $A$. heterophyllus (jackfruit). The hybrid is locally called 'Tibadak-Nangka' or 'Nanchem' since the local name for jackfruit is Nangka and A. champeden is known as Chempedak. The Nanchem fruit is larger and sweeter; the flesh is larger (Figure 3 ) and it has an attractive intense orange colour. Both $A$. champeden and its hybrid are popular edible fruits in Brunei Darussalam as well as in South East Asia due to their soft and firmly textured flesh. 


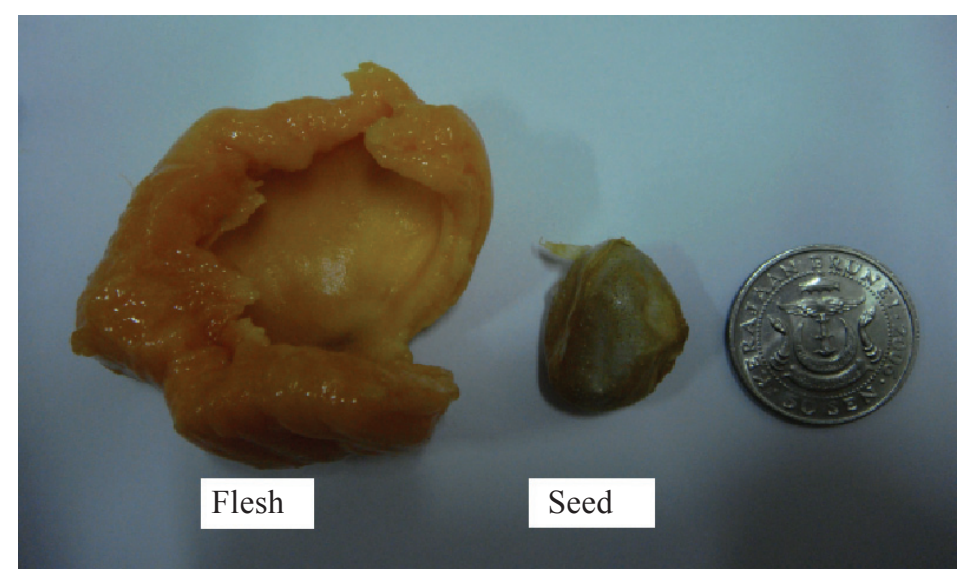

Figure 3. Nanchem flesh, seed and a 50 cent coin (diameter: $28 \mathrm{~mm}$ ) for comparison.

Various studies have been conducted on the $A$. champeden relative, $A$. heterophyllus (jackfruit). However, only a limited number of studies have been done on $A$. champeden flesh and seed. Janick and Paull (2008) have reported on the nutrient composition of $A$. champeden flesh, but the origin of the sample was not stated. Subhadrabandhu (2001) studied A. champeden flesh in Thailand, while Zabidi and Aziz (2009) have studied A. champeden seed in Malaysia.

The aim of this study was therefore to carry out a proximate analysis of the A. champeden (ripe and unripe) found in Brunei Darussalam together with its hybrid.

\section{MATERIALS AND METHODS}

All the reagents and solvents were of analytical grade and obtained from Sigma-Aldrich or Merck.

\section{Instrumentation}

The following instruments were used: A VIRTIS Specimen freeze dryer for freeze drying, a Thermolyne 1400 muffle furnace for ash, a FOSS Fibertec $^{T M} 2010$ for crude fibre, a Gerhardt automated distillation system and Kjeldhal digestion machine for the determination of crude protein, a Shimadzu UV-1601pc UV-
VIS spectrophotometer for total carbohydrate, a Gallenkamp auto bomb calorimeter for the energy and a Shimadzu AA-6701F atomic absorption flame emission spectrophotometer for the mineral analysis. All analyses were a modification of the AOAC official method (Cunniff 1998) and carried out at least in duplicate.

\section{Sample Collection}

All the fruit samples of $A$. champeden (ripe and unripe) and its hybrid (Nanchem) were purchased from the local wet markets in Bandar Seri Begawan, the capital of Brunei Darussalam, during July and August 2009. Nine fruits were bought for the ripe $A$. champeden, six fruits for the unripe $A$. champeden and nine fruits for the Nanchem.

\section{Sample Preparation}

The fruits were weighed and immediately cut open (Figure 4). The fruits were then separated into flesh, seed, skin and core. The fruits were categorized according to their flesh colour and skin texture (spikiness). The categorized parts were then weighed and kept in freezer at $-20^{\circ} \mathrm{C}$ in pre-cleaned polyethylene bags prior to analysis. The samples were extracted using the AOAC Official method 920.149 (Cunniff 1998). 


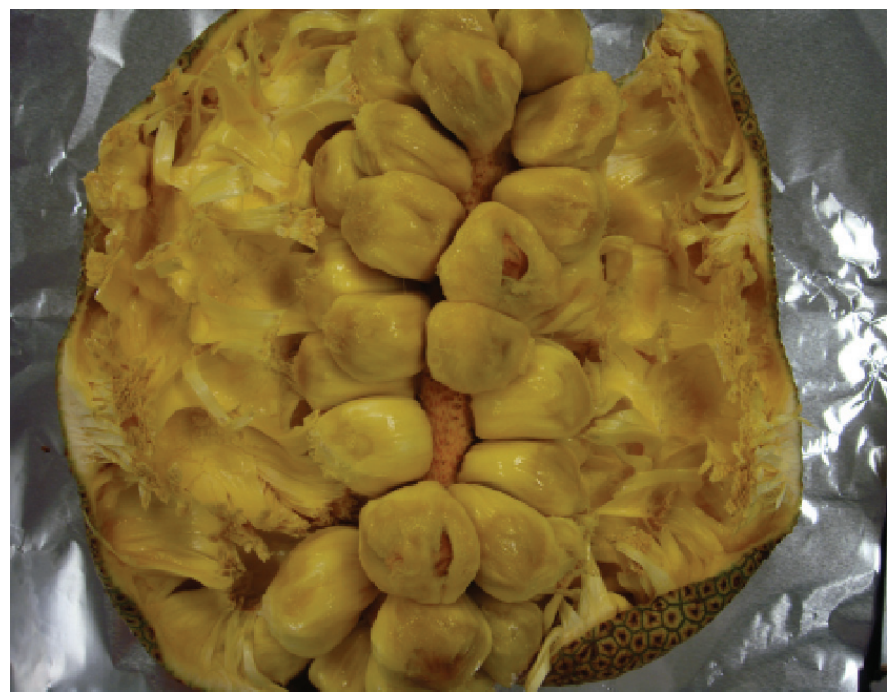

Figure 4. Cut open fruit of ripe A. champeden.

\section{Moisture Content}

Oven drying. Samples (10 g) were cut into smaller pieces and spread evenly across a preweighed drying dish. Flesh and seed samples were dried to a constant mass at $50^{\circ} \mathrm{C}$ while the skin and core were dried at $80^{\circ} \mathrm{C}$. The lower temperature was used for the flesh and seed samples in order to minimize the release of volatile components. After heating, the sample was cooled in a desiccator. Upon obtaining a constant weight, the dried sample was ground into a fine powder using a Phillips blender and stored in pre-cleaned polyethylene bags in a desiccator (Kirk \& Sawyer 1991; Ranganna 1986).

Freeze drying. Weighed A. champeden and Nanchem flesh samples were freeze-dried at $-74^{\circ} \mathrm{C}$ at a vacuum of $150-200$ millibar to constant mass; the dried samples were then stored in a desiccator.

\section{Ash}

The fresh samples $(10 \mathrm{~g})$ in silica crucibles were heated in a muffle furnace at $600^{\circ} \mathrm{C}$ for 5 h (Kirk \& Sawyer 1991; Ranganna 1986).
The ash content on a fresh weight basis was thus converted to a dry weight basis.

\section{Energy}

The energy content of the oven dried samples (flesh and seed) was determined using a bomb calorimeter; benzoic acid was used as the standard.

\section{Crude Fibre}

Determination was carried out using $2 \mathrm{~g}$ of dried sample. Sulphuric acid $(1.25 \%, 200 \mathrm{ml})$ was added and the sample was boiled for exactly $30 \mathrm{~min}$. The sulphuric acid was drained off by vacuum filtration and the sample was washed with near boiling water until traces of acid were undetected by $\mathrm{pH}$ paper. Near boiling point sodium hydroxide $(1.25 \%, 200 \mathrm{ml})$ was added into the sample followed by 2 drops of octanol and boiled for exactly $30 \mathrm{~min}$. The sodium hydroxide was drained off by vacuum filtration. The residue was washed with near boiling water $(50 \mathrm{ml})$ followed by $1.25 \%$ sulphuric acid $(30 \mathrm{ml})$ and lastly washing was repeated with near boiling water $(60 \mathrm{ml})$. The digested sample was oven-dried at $130^{\circ} \mathrm{C}$ overnight. The dried 
sample was ashed in a muffle furnace for $4 \mathrm{~h}$ at $550^{\circ} \mathrm{C}$. (Madamba 2000; Ranganna 1986).

\section{Crude Protein}

Nitrogen was determined using the modified Kjeldahl method. The dried sample (1 g), a Kjeldhal tablet with a selenium catalyst and concentrated sulphuric acid $(10 \mathrm{ml})$ were digested for $2 \mathrm{~h}$ using a Gerhardt Kjeldhal digestion machine. The distillation and titration were carried out using Gerhardt distillation system and the percentages of nitrogen were converted to protein by multiplying by 6.25 for the flesh, skin and core and 5.3 for the seed (Kirk \& Sawyer 1991; Nielsen 2003b).

\section{Crude Fat}

Crude fat was determined by Soxhlet extraction of the dried ground flesh (10 g) and seed (10 g) samples with $n$-hexane $(150 \mathrm{ml})$ for $6 \mathrm{~h}$. The $n$-hexane was removed by rotary evaporation and the yellow oil was weighed (Nielsen 2003a).

\section{Total Carbohydrate}

This analysis was carried using the phenolsulphuric acid method (AOAC Method 44.1.30), as stated in the Food Analysis Laboratory Manual (BeMiller 2003; Nielsen 2003c) with slight modification. The standard was prepared by dissolving glucose $(0.01 \mathrm{~g})$ in doubly distilled water $(100 \mathrm{ml})$.

Fresh samples (5g to $20 \mathrm{~g}$ ) were homogenized using a Philips blender in doubly distilled water $(100 \mathrm{ml})$. Known volumes of the homogenized sample were further diluted. For a ripened A. champeden and Nanchem flesh $(0.15 \mathrm{ml}$ or $0.25 \mathrm{ml})$, unripened $A$. champeden $(1 \mathrm{ml}$ or $3 \mathrm{ml})$ and the seed $(1 \mathrm{ml})$, aliquots were transferred to a $100 \mathrm{ml}$ volumetric flask and topped up using doubly distilled water. The diluted sample $(1 \mathrm{ml})$ was transferred into a test tube containing doubly distilled water $(1 \mathrm{ml})$. An $80 \%$ phenol solution $(50 \mu \mathrm{l})$ was added into the standards and samples followed by concentrated sulphuric acid $(5 \mathrm{ml})$, whereupon the colourless solution immediately became yellowish orange. The absorbance of the standards and samples were immediately recorded at $490 \mathrm{~nm}$.

\section{Mineral Analysis}

Concentrated hydrochloric acid $(2.5 \mathrm{ml})$ and concentrated nitric acid $(2.5 \mathrm{ml})$ were added to the ash. The dissolved ash was transferred into a $25 \mathrm{ml}$ volumetric flask and topped up to the mark with ultra pure water. The solutions were gravity filtered using Whatman 41 ashless filter paper into pre-cleaned plastic bottles.

\section{RESULTS AND DISCUSSION}

The proximate analysis of the ripened and unripened A. champeden and ripened Nanchem was determined for the edible portions of the fruit, viz. the flesh and seed. The analyses performed were mass composition, moisture, ash, crude fiber, crude protein, crude fat, total carbohydrate, energy and the mineral content. The results for ripened and unripened A. champeden and Nanchem flesh and seed were on a dry weight basis except for total carbohydrate which was done on a fresh weight basis.

\section{Physical Description}

A. champeden fruit weights from $1 \mathrm{~kg}$ to $3.5 \mathrm{~kg}$ and the average length of the fruit is $23 \mathrm{~cm}$ which is smaller with $A$. heterophyllus (jackfruit). Both $A$. champeden and $A$. heterophyllus (jackfruit) have a green, yellow or brown skin that is divided into small hexagons and the texture of the skin is either smooth or spiky (Figure 1). Like A. heterophyllus (jackfruit), the colour of the flesh is golden yellow to orange while the seed is brown in colour and is surrounded by the yellow flesh (Figure 2). The texture of the A. champeden flesh is soft, while for $A$. heterophyllus (jackfruit) the flesh is crunchy. Both A. champeden flesh 
and seed are edible, but its skin and core are normally discarded.

Nanchem fruit weighs from 1 to $5 \mathrm{~kg}$ and the fruit average length is about $30 \mathrm{~cm}$. The shape of the fruit is elongated like $A$. champeden. It has similar skin texture and flesh color with $A$. champeden and A. heterophyllus. However, Nanchem's skin is spikier (Figure 5) than $A$. champeden and divided into small pyramidal hexagons. When Nanchem is cut opened (Figure 4), the flesh is attached to a light brown colored core which is hairy and is about 10 $\mathrm{cm}$ in length. Nanchem flesh is thicker and is bright orange or yellow in color (Figure 3 ). The seed is surrounded by its flesh. The seed on the other hand is smaller than A. champeden and $A$. heterophyllus.

\section{Mass Composition}

The average amount of flesh in ripe $A$. champeden was $26.5 \%$ (9 fruits) while that for unripe A. champeden (6 fruits) and Nanchem (9 fruits) is $24.4 \%$ each. Nanchem flesh was more fibrous and juicier than the ripe $A$. champeden; this might account for its popularity in Brunei Darussalam.

Table 1 shows the mass composition of the samples. The seed content in ripe and unripe
A. champeden and Nanchem are $31.4 \%, 16.9 \%$ and $6.8 \%$ respectively. The ripe $A$. champeden has the most seeds with larger seeds compared to Nanchem (Figure 2 and Figure 3).

The skin and core are inedible and are always treated as waste in Brunei Darussalam. The skin is the heaviest part of the fruit, while the core is the lightest part. Nanchem has more skin than A. champeden. However, unripe $A$. champeden has more skin than its ripe specimens. Since the fruit is usually traded based on its weight, the Nanchem has the least value for money as the inedible portion (skin and core) amounts to almost $69 \%$ of the whole fruit compared to only $42 \%$ for the ripe $A$. champeden.

As the Nanchem fruit consists of about $70 \%$ skin, it would be profitable if the skin could be utilized. For example, it has been shown that A. heterophyllis (jackfruit) skin removes methylene blue (Prahas et. al. 2008) and cadmium(II) ions (Inbaraj \& Sulochana 2004) from aqueous solution. Therefore, Nanchem skin could be used as a bio-sorbent to absorb the impurities in water rather than being disposed as waste. On the other hand, the seed that is normally eaten boiled could be used in baking replacing wheat flour like $A$. heterophyllus (jackfruit) (Zabidi \& Aziz 2009).

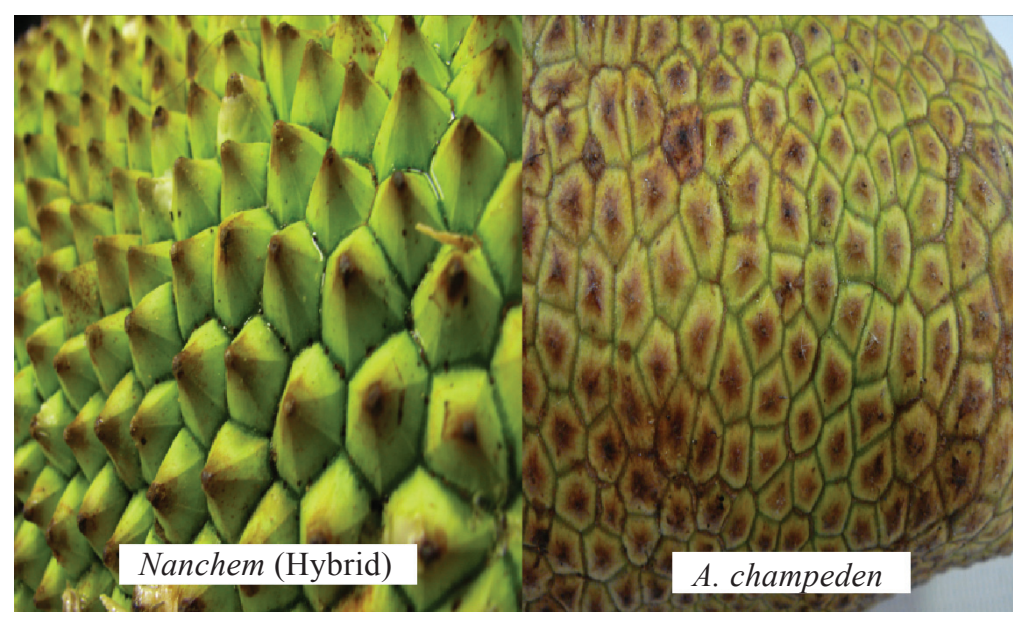

Figure 5. Nanchem (hybrid) (left) and A. champeden (right) skin texture. 
Table 1. Mean mass composition (\%) of A. champeden and Nanchem fruit.

\begin{tabular}{cl|ccccc}
\hline \multicolumn{2}{c|}{ Type } & $\mathrm{n}^{\mathrm{a}}$ & Flesh & Seed & Skin & Core \\
\hline \multirow{2}{*}{ Champeden } & Ripe & 9 & 26.5 & 31.4 & 36.8 & 5.4 \\
& Unripe & 6 & 24.4 & 16.9 & 52.4 & 6.4 \\
Nanchem & Hybrid & 9 & 24.4 & 6.8 & 63.5 & 5.3 \\
\hline
\end{tabular}

${ }^{\mathrm{a}} \mathrm{n}$ represents the number of samples.

\section{Moisture Content}

The moisture content of the fruit was determined by both oven-drying and freeze-drying. The moisture content in ripe and unripe $A$. champeden flesh was in the range of $62.3 \%-$ $73.4 \%$ and $82.7 \%-88.1 \%$, respectively. For its hybrid flesh, the moisture content was within the range of $59.7 \%-69.5 \%$. The range $58 \%-$ $87 \%$ has been reported by Janick \& Paull (2008) and Subhadrabandhu (2001) in Thailand. The moisture in Nanchem flesh was lower than $A$. heterophyllus (jackfruit) (72-94\%) and was similar to $A$. champeden. Unripe $A$. champeden had the highest moisture content which was similar to the moisture content in vegetables $(80 \%-90 \%)$ (Kirk \& Sawyer 1991).

The moisture content in the seeds of ripe and unripe $A$. champeden and Nanchem was in the range $52.9-91.1 \%$. The range $46 \%$ $78 \%$ has been reported by Subhadrabandhu
(2001) and Zabidi \& Aziz (2009). Unripe $A$. champeden $(83.6 \%-91.1 \%)$ contained the highest percentage of moisture in its seed. Ripe A. champeden's seed (52.9\% - 72.8\%) contained more moisture than the Nanchem seed (49.7\% $54.0 \%$ ), but lower than the highmoisture content in A. heterphyllus (jackfruit) (64\%). Water in fruit plays a part in controlling the microbial activity and high moisture content will reduce the shelf life of a particular fruit (Chowdhury et al. 1997). The order for moisture content in ripe $A$. champeden and Nanchem was: flesh > seed and no trends was evident for unripe $A$. champeden.

Figure 6 shows that both drying methods yield similar moisture content for the samples (ripe A. champeden and Nanchem). In spite of this, the appearance of the dried samples were dissimilar. For oven dried, the sample turned from a yellow to a dark-brown colour

Table 2. Proximate analyses of A. champeden and Nanchem flesh and seeds ${ }^{\mathrm{a}}$.

\begin{tabular}{|c|c|c|c|c|c|c|}
\hline \multirow{3}{*}{ Analysis (\%) } & \multicolumn{3}{|c|}{ Flesh } & \multicolumn{3}{|c|}{ Seed } \\
\hline & \multicolumn{2}{|c|}{ A. champeden } & \multirow{2}{*}{ Nanchem } & \multicolumn{2}{|c|}{ A. champeden } & \multirow{2}{*}{ Nanchem } \\
\hline & Ripe & Unripe & & Ripe & Unripe & \\
\hline Moisture & $62.3-73.4$ & $82.7-88.1$ & $59.7-69.5$ & $52.9-72.8$ & $83.6-91.1$ & $49.7-54.0$ \\
\hline Ash & $2.5-3.9$ & $4.6-5.0$ & $2.2-2.7$ & $3.2-5.1$ & $4.0-5.0$ & $2.8-3.2$ \\
\hline Crude Fibre & $4.6-7.6$ & $12.9-23.9$ & $2.5-3.3$ & $3.9-7.1$ & $8.0-8.3$ & $4.7-8.5$ \\
\hline Crude Protein & $4.9-5.8$ & $7.3-15.9$ & $4.1-7.5$ & $9.9-11.2$ & $12.1-17.9$ & $8.9-10.9$ \\
\hline Crude Fat & $2.4-3.5$ & $3.9-6.4$ & $0.8-4.1$ & $0.8-2.4$ & $1.5-2.3$ & $0.9-1.7$ \\
\hline $\begin{array}{l}\text { Total Carbohydrate } \\
(\mathrm{g} / 100 \mathrm{~g})\end{array}$ & $16.2-28.3$ & $2.4-5.1$ & $7.5-30.0$ & $2.8-3.5$ & $1.8-2.5$ & $3.2-3.4$ \\
\hline Energy (kcal/100g ) & $430-437$ & $456-463$ & $456-477$ & $431-447$ & $467-539$ & $465-480$ \\
\hline
\end{tabular}

${ }^{a}$ All analyses were performed in dry samples, except for total carbohydrate which was carried out on a fresh weight basis. 
after drying while for freeze dried, the sample retained its original colour and odour. The contributing factors for the change in colour on heating are the Maillard reaction and enzymatic reactions (Chong et al. 2009). The texture of the sample turned hard and springy when oven-dried.

According to Chong et al. (2009), the quality of the dried fruit is higher if it is soft. Hence, the freeze-drying method is believed to produce a higher quality of dried sample due to the soft dried fruit obtained after drying, and this technique protects the primary structure of the sample by solidifying the water. On the other hand, the springiness in oven-drying sample is due to the gelling agents in the fruits such as pectin. A high temperature could induce the pectin substances in fruit to restructure and therefore cause the oven-dried sample to be hard and springy. In terms of time however, oven-drying was preferable.

\section{Ash}

The ash in the flesh of ripe A.champeden and Nanchem was $2.5 \%-3.9 \%$ and $2.2 \%-2.7 \%$, respectively. These results were similar to the reported values of $A$. champeden: $1.2 \%$ (Janick \& Paull 2008) and 2\% - 4\% (Subhadrabandhu 2001) (Table 3). Unripe A. champeden had more ash $(4.6 \%-5.0 \%)$ compared to the ripe fruit and Nanchem.
For the seeds, both ripe A. champeden and Nanchem had similar ash content with the reported values $(2.6 \%-4.0 \%)$ (Subhadrabandhu 2001; Zabidi \& Aziz 2009) (Table 4). Unripe A. champeden seed $(4.0 \%-5.0 \%)$ had more ash than the ripe $A$. champeden $(3.2 \%-5.1 \%)$ and Nanchem $(2.8 \%-3.2 \%)$. For ripe $A$. champeden and Nanchem, the amount of ash in the seed was higher than that in the flesh. However, unripe A. champeden had a similar amount of ash for both flesh and seed.

\section{Crude Fibre}

Unripe A. champeden flesh and seeds had more crude fibre than the ripe fruit and the hybrid species (Table 2). Ripe and unripe $A$. champeden flesh contained more crude fibre than the seed while Nanchem seed has more crude fibre than its flesh. Unripe $A$. champeden flesh $(12.9 \%-23.9 \%)$ had the highest amount of crude fibre followed by ripe $A$. champeden (4.6\% - 7.6\%) and Nanchem $(2.5 \%-3.3 \%)$. Crude fibre values of $3.4 \%$ and $5 \%-6 \%$ were reported by Janick \& Paull (2008) and Subhadrabandhu (2001) (Table 3), respectively for A. champeden flesh. Generally, the order for ripe and unripe $A$. champeden was: flesh $>$ seed, whereas the order for Nanchem was: seed $>$ flesh.

For seeds, the crude fibre value reported by Zabidi \& Aziz (2009) (2.44\%) (Table 4) is lower

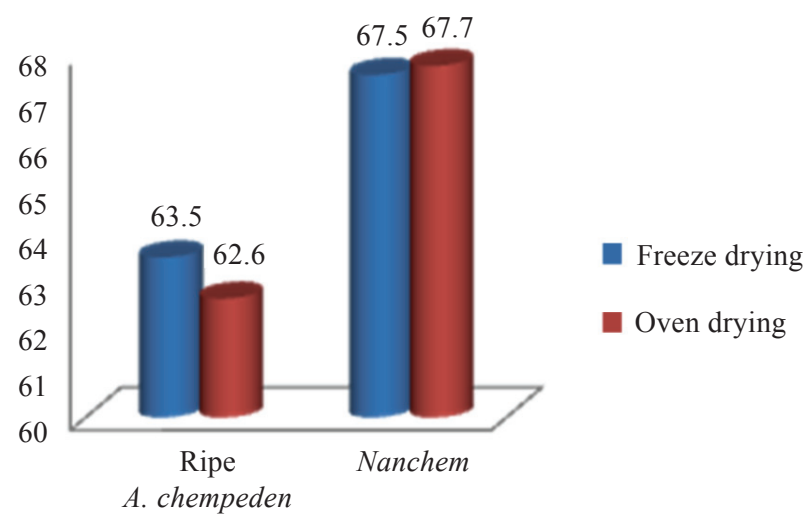

Figure 6. Moisture content (\%) of the oven dried and freeze dried flesh. 
for A. champeden flesh. Generally, the order for ripe and unripe $A$. champeden was: flesh $>$ seed, whereas the order for Nanchem was: seed $>$ flesh.

For seeds, the crude fibre value reported by Zabidi \& Aziz (2009) (2.44\%) (Table 4) is lower than the values obtained in this study. However, the value reported by Subhadrabandhu (2001) is $4 \%-6 \%$ which was similar to the ripe $A$. champeden and Nanchem. On the other hand, crude fibre value for A. heterophyllus reported by Haq (2006) was $1.3 \%$ which was lower than ripe A. champeden and Nanchem seeds.

\section{Crude Protein}

Unripe $A$. champeden flesh was the highest source of crude protein $(7.3 \%-15.9 \%)$ compared with Nanchem $(4.1 \%-7.5 \%)$ and ripe $A$. champeden $(5.0 \%-5.8 \%)$. In terms of the ripe species, Nanchem contained slightly more crude protein than A. champeden. Janick \& Paull (2008) and Subhadrabandhu (2001) reported values in the range of $2.5 \%-7.0 \%$ (Table 3). Nanchem flesh had a similar amount of crude protein as the reported value for ripe A. champeden (2.5\% and 3.5\% - 7.0\%) (Janick \& Paull 2008; Subhadrabandhu 2001), but higher than A. heterophyllus (jackfruit) (1.6\%) (Janick \& Paull 2008). In terms of flesh, the order was: unripe $A$. champeden $>$ Nanchem $>$ ripe $A$. champeden .

Generally, the seed contains more crude protein than its flesh; this is quite reasonable as most seed samples are a rich source of protein (Zabidi \& Aziz 2009). Similar to its flesh, unripe A. champeden seed $(12.1 \%-17.9 \%)$ contained more crude protein than ripe $A$. champeden $(9.9 \%-11.2 \%)$ and Nanchem (8.9\% - 10.9\%). This was a reverse for Nanchem as the seed had a lower percentage of crude protein than the ripe A. champeden. Therefore, the order of crude protein for the seed was: unripe $A$. champeden $>$ ripe $A$. champeden $>$ Nanchem.
Crude protein of $A$. champeden seeds reported by Subhadrabandhu (2001) and Zabidi \& Aziz (2009) are 10\% - 13\% and 12.88\% (Table 4), respectively. These values were similar to the amount of crude protein in ripe A. champeden and Nanchem. However, unripe A. champeden seeds contained more crude protein than ripe $A$. champeden, Nanchem and the values reported by Subhadrabandhu (2001), and Zabidi and Aziz (2009). Since Nanchem is the hybrid of $A$. champeden and A. heterophyllus (jackfruit), a comparison between $A$. champeden and Nanchem was made. Nanchem seeds contained more crude protein than $A$. heterophyllus (jackfruit) $(6.6 \%)$ and its value was more similar to that of ripe $A$. champeden.

\section{Crude Fat}

For the flesh, the percentage of crude fat was slightly higher than the reported values $(0.4 \%$ $-2.0 \%$ ) (Janick \& Paull 2008; Subhadrabandhu 2001) (Table 3) for all species. For example, the percentage of crude fat for ripe and unripe A. champeden and Nanchem was in the range of $2.4 \%-3.5 \%, 3.9 \%-6.4 \%$ and $0.8 \%-$ $4.1 \%$, respectively. Unripe $A$. champeden flesh contained more crude fat than the ripe $A$. champeden which contained more crude fat than its hybrid (Nanchem). Generally, the order of crude fat for flesh was: unripe $A$. champeden $>$ ripe A. champeden $>$ Nanchem.

The crude fat for ripe and unripe $A$. champeden and Nanchem seeds was $0.8 \%-2.4 \%, 1.5 \%-$ $2.3 \%$ and $0.9 \%-1.7 \%$ respectively. The crude fat reported by Subhadrabandhu (2001) on $A$. champeden seed is $0.5 \%-1.5 \%$ (Table 4 ) while the crude fat in A. heterophyllus (jackfruit) seed was only $0.4 \%$. Ripe $A$. champeden contained somewhat more crude fat than the unripe and hybrid species. The seeds had less crude fat than the flesh; the order of crude fat for seed samples was: ripe $A$. champeden $>$ unripe $A$. champeden $>$ Nanchem. 


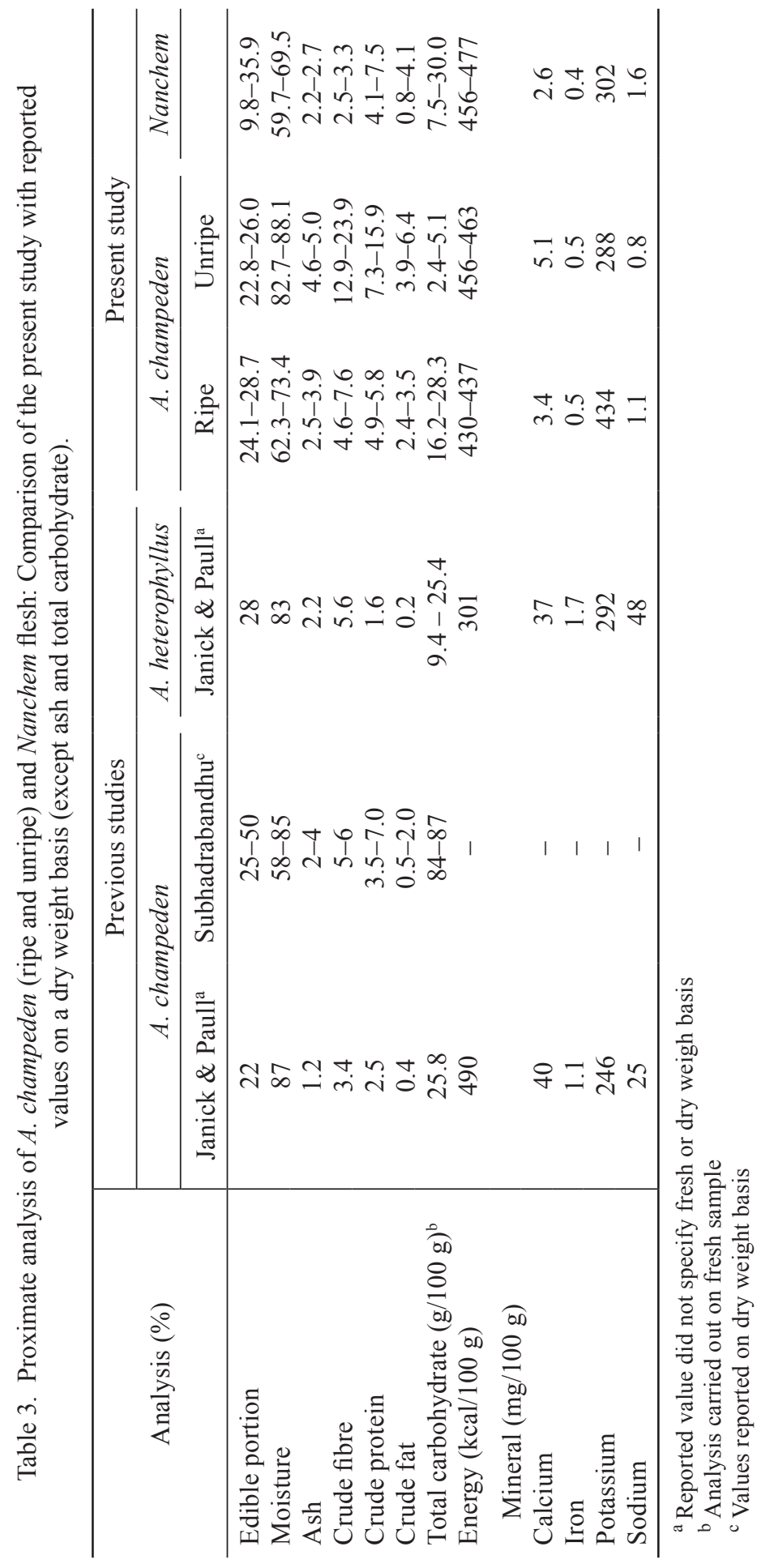


than the values obtained in this study. However, the value reported by Subhadrabandhu (2001) is $4 \%-6 \%$ which was similar to the ripe $A$. champeden and Nanchem. On the other hand, crude fibre value for $A$. heterophyllus reported by Haq (2006) was $1.3 \%$ which was lower than ripe $A$. champeden and Nanchem seeds.

\section{Crude Protein}

Unripe A. champeden flesh was the highest source of crude protein $(7.3 \%-15.9 \%)$ compared with Nanchem $(4.1 \%-7.5 \%)$ and ripe $A$. champeden $(5.0 \%-5.8 \%)$. In terms of the ripe species, Nanchem contained slightly more crude protein than A. champeden. Janick \& Paull (2008) and Subhadrabandhu (2001) reported values in the range of $2.5 \%-7.0 \%$ (Table 3). Nanchem flesh had a similar amount of crude protein as the reported value for ripe A. champeden $(2.5 \%$ and $3.5 \%-7.0 \%)$ (Janick \& Paull 2008; Subhadrabandhu 2001), but higher than A. heterophyllus (jackfruit) (1.6\%) (Janick \& Paull 2008). In terms of flesh, the order was: unripe $A$. champeden $>$ Nanchem $>$ ripe $A$. champeden.

Generally, the seed contains more crude protein than its flesh; this is quite reasonable as most seed samples are a rich source of protein (Zabidi \& Aziz 2009). Similar to its flesh, unripe A. champeden seed $(12.1 \%-17.9 \%)$ contained more crude protein than ripe $A$. champeden $(9.9 \%-11.2 \%)$ and Nanchem (8.9\% - 10.9\%). This was a reverse for Nanchem as the seed had a lower percentage of crude protein than the ripe A. champeden. Therefore, the order of crude protein for the seed was: unripe $A$. champeden $>$ ripe $A$. champeden $>$ Nanchem.

Crude protein of $A$. champeden seeds reported by Subhadrabandhu (2001) and Zabidi \& Aziz (2009) are 10\% - 13\% and $12.88 \%$ (Table 4), respectively. These values were similar to the amount of crude protein in ripe A. champeden and Nanchem. However, unripe A. champeden seeds contained more crude protein than ripe $A$. champeden, Nanchem and the values reported by Subhadrabandhu (2001), and Zabidi and Aziz (2009). Since Nanchem is the hybrid of $A$. champeden and A. heterophyllus (jackfruit), a comparison between $A$. champeden and Nanchem was made. Nanchem seeds contained more crude protein than $A$. heterophyllus (jackfruit) $(6.6 \%)$ and its value was more similar to that of ripe $A$. champeden.

\section{Crude Fat}

For the flesh, the percentage of crude fat was slightly higher than the reported values $(0.4 \%$ -2.0\%) (Janick \& Paull 2008; Subhadrabandhu 2001) (Table 3) for all species. For example, the percentage of crude fat for ripe and unripe A. champeden and Nanchem was in the range of $2.4 \%-3.5 \%, 3.9 \%-6.4 \%$ and $0.8 \%-$ $4.1 \%$, respectively. Unripe A. champeden flesh contained more crude fat than the ripe $A$. champeden which contained more crude fat than its hybrid (Nanchem). Generally, the order of crude fat for flesh was: unripe $A$. champeden $>$ ripe $A$. champeden $>$ Nanchem.

The crude fat for ripe and unripe $A$. champeden and Nanchem seeds was $0.8 \%-2.4 \%, 1.5 \%-$ $2.3 \%$ and $0.9 \%-1.7 \%$ respectively. The crude fat reported by Subhadrabandhu (2001) on $A$. champeden seed is $0.5 \%-1.5 \%$ (Table 4 ) while the crude fat in A. heterophyllus (jackfruit) seed was only $0.4 \%$. Ripe $A$. champeden contained somewhat more crude fat than the unripe and hybrid species. The seeds had less crude fat than the flesh; the order of crude fat for seed samples was: ripe $A$. champeden $>$ unripe $A$. champeden $>$ Nanchem.

\section{Total Carbohydrate}

Ripe samples of fruit normally contain more carbohydrates than the unripe samples. Total carbohydrates (fresh cut) for ripe $A$. champeden was $16.2 \%-28.3 \mathrm{~g} / 100 \mathrm{~g}$ which was comparable to the reported value $(25.8 \mathrm{~g} / 100 \mathrm{~g})$ (Janick \& 


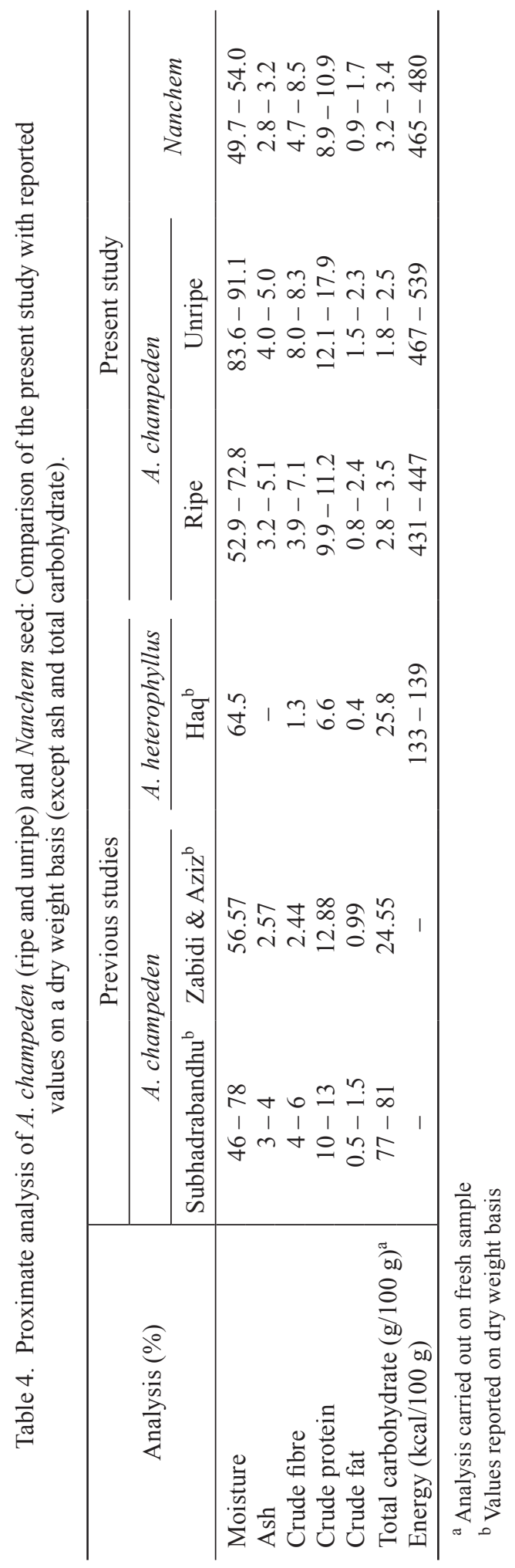


Paull 2008; Subhadrabandhu 2001) (Table 3) and was similar to A. heterophyllus $(9.4 \%-25.4$ g/100 g) (Haq 2006; Janick \& Paull 2008). The total carbohydrates for Nanchem $(7.5 \%-30.0$ $\mathrm{g} / 100 \mathrm{~g})$ was similar to the reported values for A. heterophyllus (jackfruit) $(9.4 \%-25.4 \mathrm{~g} / 100$ g) (Haq 2006) and A. champeden (25.8 g/100 g) (Janick \& Paull 2008; Subhadrabandhu 2001). Hence, Nanchem's flesh contained more total carbohydrates than ripe $A$. champeden. The order of total carbohydrate for the flesh was: Nanchem $>$ ripe $A$. champeden $>$ unripe $A$. champeden.

The total carbohydrate for the seed on the other hand was very much lower than its flesh. Total carbohydrates in ripe A. champeden $(2.8 \%$ $-3.5 \mathrm{~g} / 100 \mathrm{~g})$ and Nanchem $(3.2 \%-3.4 \mathrm{~g} / 100$ g) were similar. Unripe A. champeden had the lowest total carbohydrate $(1.8 \%-2.5 \mathrm{~g} / 100 \mathrm{~g})$. However, the total carbohydrate of the seed in this study was not comparable with the values reported by Subhadrabandhu (2001), Zabidi and Aziz (2009) and Haq (2006) (Table 4) because it was done in fresh weight. As a result, the order of total carbohydrate for seed was: ripe $A$. champeden $\approx$ Nanchem $\approx$ unripe $A$. champeden .

\section{Energy}

Nanchem flesh (456-477 kcal/100 g) provided more energy than the $A$. champeden, whereas unripe $A$. champeden flesh had somewhat more energy than its ripe flesh. The energy of A. champeden (Janick \& Paull 2008) and A. heterophyllus (Haq 2006; Janick \& Paull 2008) flesh was $490 \mathrm{kcal} / 100 \mathrm{~g}$ and $301 \mathrm{kcal} / 100 \mathrm{~g}$ (Table 3), respectively. Therefore, ripe $A$. champeden and Nanchem energy content was slightly lower with the values reported by Janick \& Paull (2008) on $A$. champeden. The reported value for A. heterophyllus (jackfruit) appeared to be unusually low. The order of energy content in flesh was: Nanchem $\approx$ unripe $A$. champeden $>$ ripe $A$. champeden .
Unripe A. champeden seed (467 - 539 $\mathrm{kcal} / 100 \mathrm{~g}$ ) provided more energy when eaten compared to the ripe $A$. champeden (431 $447 \mathrm{kcal} / 100 \mathrm{~g})$ and Nanchem $(465$ - 480 $\mathrm{kcal} / 100 \mathrm{~g}$ ). However, the reported value for A. heterophyllus (jackfruit) seed is $133-139$ $\mathrm{kcal} / 100 \mathrm{~g}$ (Haq 2006) (Table 4) which is dramatically lower than the values obtained in this study. No values had been reported on the energy content of $A$. champeden seed.

\section{Minerals}

The mineral (nutrient) composition of $A$. champeden (ripe and unripe) and Nanchem were determined on its flesh and seed on a fresh weight basis (Table 5).

Potassium was the prevalent mineral followed by $\mathrm{Mg}, \mathrm{Mn}, \mathrm{Ca}, \mathrm{Zn}, \mathrm{Na}, \mathrm{Cu}, \mathrm{Fe}, \mathrm{Co}$ and Ni respectively, in the flesh and seed. The amounts of potassium in flesh and seed are shown in Figure 7. Ripe A. champeden and Nanchem seed contained a higher amount of potassium than its flesh. This trend was however a reversed for the unripe $A$. champeden. The amount of potassium in ripe $A$. heterophyllus (jackfruit) is $292 \mathrm{mg} / \mathrm{g}$ (Janick \& Paull 2008) (Table 3) which was lower than the amount reported in this study. On the other hand, the amount of potassium in unripe $A$. champeden flesh $(288 \mathrm{mg} / 100 \mathrm{~g})$ was similar to the unripe $A$. heterophyllus (287 - $323 \mathrm{mg} / 100 \mathrm{~g}$ ) (Haq 2006).

The other major element present in the flesh and seed was magnesium (Figure 8). Similarly to potassium, ripe $A$. champeden and Nanchem seeds yielded a higher quantity of $\mathrm{Mg}$ than its flesh, while the reverse was seen between the unripe $A$. champeden flesh and seed.

$\mathrm{Mn}, \mathrm{Ca}, \mathrm{Zn}, \mathrm{Na}, \mathrm{Cu}, \mathrm{Fe}, \mathrm{Co}$ and $\mathrm{Ni}$ were treated as minor elements in this study because they are found at a concentration of less than 
Table 5. Mineral content for A. champeden (ripe and unripe) and Nanchem flesh and seed $(\mathrm{mg} / 100 \mathrm{~g})$ on a fresh weight basis ${ }^{\mathrm{a}}$.

\begin{tabular}{|c|c|c|c|c|c|c|}
\hline \multirow{3}{*}{$\begin{array}{c}\text { Mineral } \\
(\mathrm{mg} / 100 \mathrm{~g})\end{array}$} & \multicolumn{3}{|c|}{ Flesh } & \multicolumn{3}{|c|}{ Seed } \\
\hline & \multicolumn{2}{|c|}{ A. champeden } & \multirow{2}{*}{ Nanchem } & \multicolumn{2}{|c|}{ A. champeden } & \multirow{2}{*}{ Nanchem } \\
\hline & Ripe & Unripe & & Ripe & Unripe & \\
\hline K & $434 \pm 38$ & $288 \pm 17$ & $302 \pm 53$ & $609 \pm 33$ & $250 \pm 61$ & $594 \pm 25$ \\
\hline $\mathrm{Mg}$ & $46 \pm 6$ & $41 \pm 3$ & $42 \pm 7$ & $65 \pm 11$ & $32 \pm 6$ & $87 \pm 3$ \\
\hline $\mathrm{Mn}$ & $4.3 \pm 1.0$ & $5.2 \pm 0.6$ & $3.9 \pm 0.2$ & $5.5 \pm 0.7$ & $5.1 \pm 1.1$ & $0.7 \pm 0.3$ \\
\hline $\mathrm{Ca}$ & $3.4 \pm 1.5$ & $5.1 \pm 1.4$ & $2.6 \pm 0.5$ & $2.9 \pm 0.6$ & $2.3 \pm 0.3$ & $3.1 \pm 0.2$ \\
\hline $\mathrm{Zn}$ & $2.0 \pm 0.0$ & $1.9 \pm 0.9$ & $1.2 \pm 0.0$ & $1.9 \pm 0.4$ & $0.9 \pm 0.3$ & $1.1 \pm 0.1$ \\
\hline $\mathrm{Na}$ & $1.1 \pm 0.1$ & $0.8 \pm 0.1$ & $1.6 \pm 0.3$ & $1.2 \pm 0.2$ & $0.8 \pm 0.3$ & $0.9 \pm 0.1$ \\
\hline $\mathrm{Cu}$ & $1.1 \pm 0.0$ & $1.0 \pm 0.2$ & $1.0 \pm 0.1$ & $1.0 \pm 0.0$ & $0.7 \pm 0.2$ & $1.0 \pm 0.0$ \\
\hline $\mathrm{Fe}$ & $0.5 \pm 0.0$ & $0.5 \pm 0.0$ & $0.4 \pm 0.0$ & $0.7 \pm 0.1$ & $0.6 \pm 0.0$ & $0.7 \pm 0.0$ \\
\hline Co & $0.4 \pm 0.0$ & $0.3 \pm 0.1$ & $0.3 \pm 0.0$ & $0.3 \pm 0.0$ & $0.2 \pm 0.1$ & $0.3 \pm 0.0$ \\
\hline $\mathrm{Ni}$ & $0.2 \pm 0.0$ & $0.2 \pm 0.0$ & $0.2 \pm 0.0$ & $0.2 \pm 0.0$ & $0.2 \pm 0.1$ & $0.2 \pm 0.2$ \\
\hline $\mathrm{Cd}$ & $0.1 \pm 0.0$ & $0.1 \pm 0.0$ & $0.1 \pm 0.0$ & $0.1 \pm 0.0$ & $0.1 \pm 0.0$ & $0.1 \pm 0.0$ \\
\hline $\mathrm{Pb}$ & & Not detectec & & & Not detectec & \\
\hline
\end{tabular}

${ }^{\mathrm{a}}$ The mean of two replicates \pm deviation

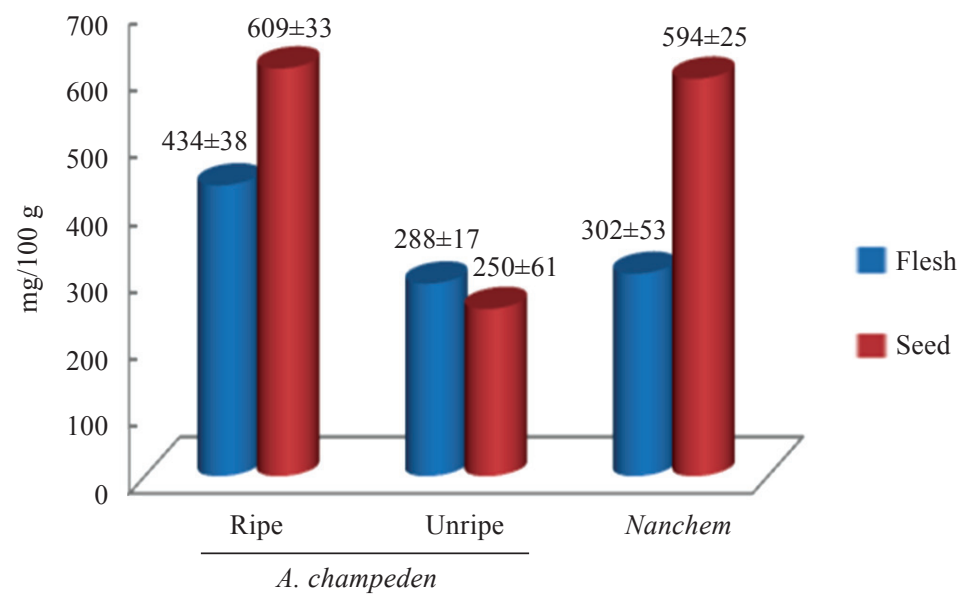

Figure 7. Potassium content in A. champeden (ripe and unripe) and Nanchem flesh and seeds ( $\mathrm{mg} / 100 \mathrm{~g})$, fresh weight basis, the mean of two replicates \pm deviation.

$10 \mathrm{mg} / 100 \mathrm{~g}$ (Table 5), (Figure 9 and Figure 10). However, a small amount of cadmium was also detected in the flesh and seed samples, at about $0.1 \mathrm{mg} / 100 \mathrm{~g}$. As suggested by FAO/ WHO, a possible source of cadmium is due to soil contamination as cadmium could be easily absorbed by roots (Boisset \& Narbonne 1995). Lead was opportunely not detected in any of the samples.

\section{CONCLUSION}

In terms of the flesh, unripe $A$. champeden was more nutritive than ripe $A$. champeden and its hybrid, Nanchem, in the area of ash, crude fiber and crude protein. In contrast, both ripe A. champeden and Nanchem had more total carbohydrates than unripe $A$. champeden. Unripe $A$. champeden is always eaten as a vegetable due to the lower sweetness. In terms 


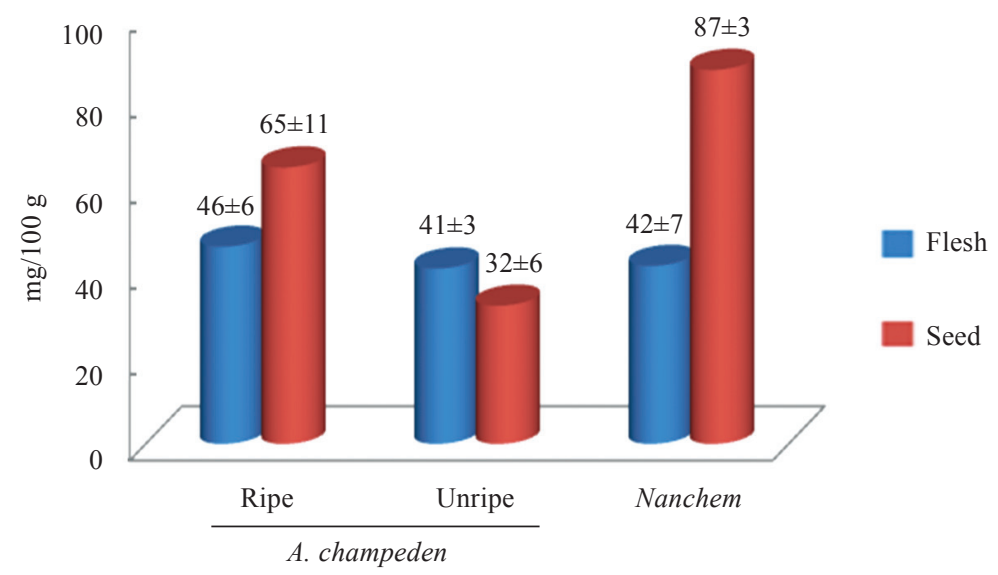

Figure 8. Magnesium content in A. champeden (ripe and unripe) and Nanchem flesh and seeds ( $\mathrm{mg} / 100 \mathrm{~g})$, fresh weight basis.

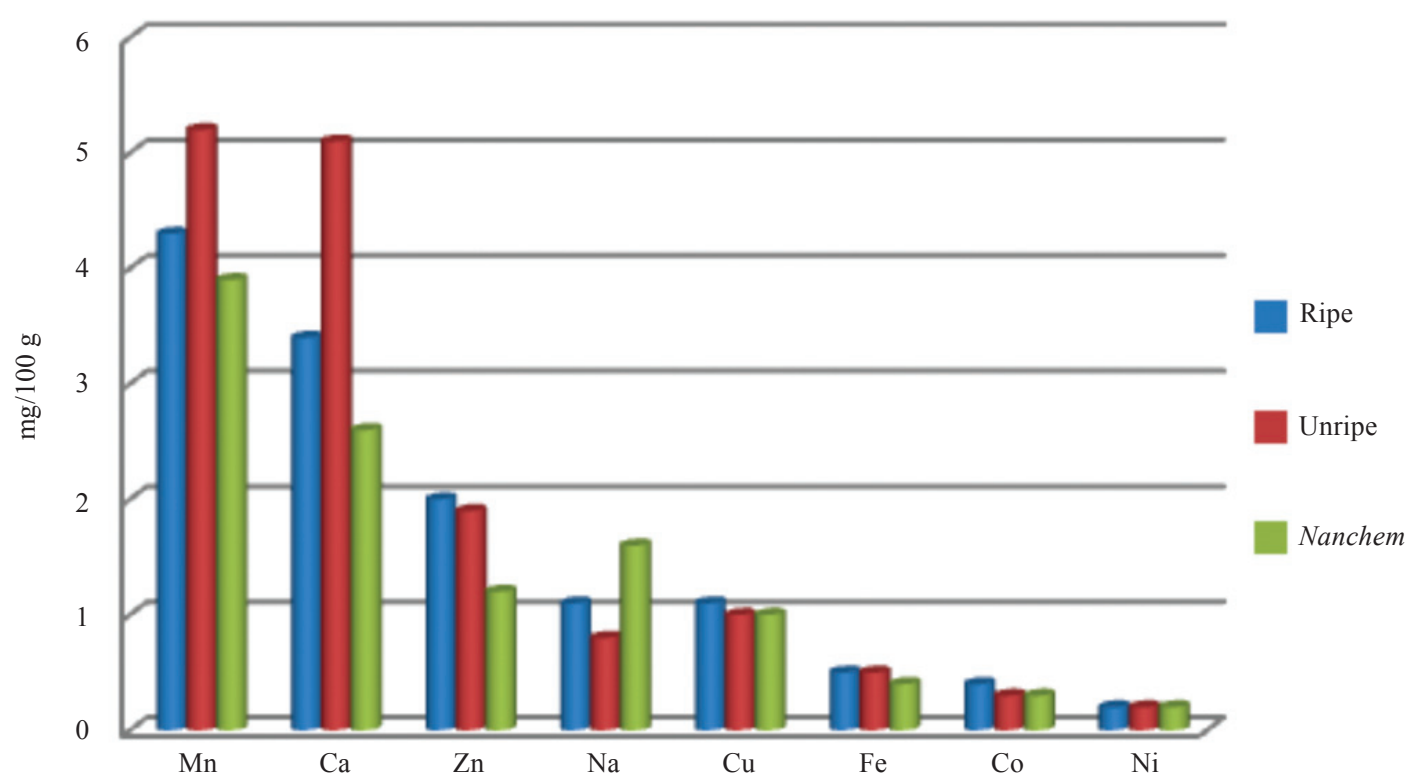

Figure 9. Minor elements present in A. champeden (ripe and unripe) and Nanchem flesh (mg/100 g), fresh weight basis.

of its high moisture content, it resembles a vegetable. The amount of sweetness in fruit is related to the total carbohydrates, but it also depends on its maturity, growing location and temperature (Kirk \& Sawyer 1991).

Similar to the flesh, unripe $A$. champeden seed provided higher values for moisture, ash, crude fiber, crude protein, crude fat and energy than the ripe $A$. champeden and Nanchem seed. The similarities found between ripe $A$. champeden and Nanchem seed were moisture, crude protein, crude fat and total carbohydrate.

$\mathrm{K}$ and $\mathrm{Mg}$ were the prevalent minerals in the flesh and seed samples, while $\mathrm{Mn}, \mathrm{Ca}, \mathrm{Cu}$, $\mathrm{Fe}, \mathrm{Co}$ and $\mathrm{Ni}$ was present in quantities of less than $10 \mathrm{mg} / 100 \mathrm{~g}$. 


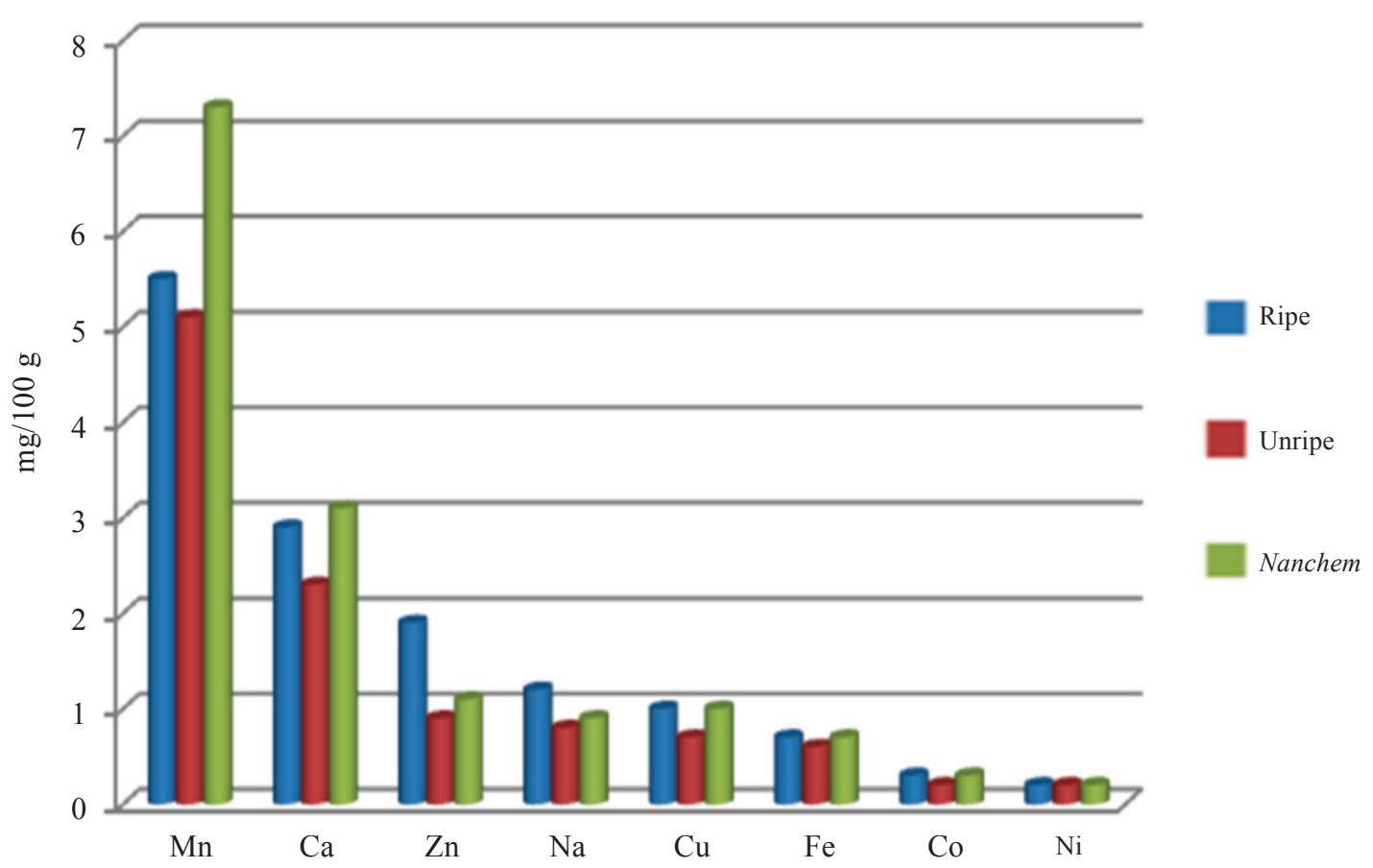

Figure 10 Minor elements present in A. champeden (ripe and unripe) and Nanchem seed ( $m g / 100 \mathrm{~g})$, fresh weight basis

The nutrient components in the flesh and seeds of Nanchem were closer to A. champeden in terms of moisture, ash, crude protein and crude fat, while Nanchem flesh resembled $A$. heterophyllus (jackfruit) in terms of ash and total carbohydrate. Therefore, it appeared that Nanchem had the characteristics of both $A$. champeden and A. heterophyllus.

\section{ACKNOWLEDGEMENTS}

The authors would like to thank Universiti Brunei Darussalam and the Government of Brunei Darussalam for their financial support for this project and the Brunei Agriculture Research Center for the use of their equipment for crude fibre and protein analysis.

Date of submission: June 2011 Date of acceptance: September 2011

\section{REFERENCES}

Bailey, LH 1942, The standard encyclopedia of horticulture, The Macmillan Co., New York.

BeMiller, JN 2003, 'Carbohydrate analysis', in Food analysis, 3rd edn., ed SS Nielsen, Kluwer Academic, New York.

Boisset, M \& Narbonne, J-F 1995, Cadmium in food, Council of Europe, Narbonne.

Boonlaksiri, C, Oonanant, W, Kongsaeree, P, Kittakoop, P, Tanticharoen, M \& Thebtaranonth, Y 2000, 'Anantimalarial stilbene from Artocarpus integer, Phytochemistry, vol. 54, no. 4, pp. 415 -417 .

Chong, CH, Law, CL, Cloke, M, Hii, CL, Abdullah, LC \& Daud, WR 2009, 'Drying kinetics and product quality of dried Chempedak', Journal of Food Engineering, vol. 88, no. 4, 522 - 527.

Chowdhury, FA, Raman, MA, \& Mian, AJ 1997, 'Distribution of free sugars and fatty acids in jackfruit (Artocarpus heterophyllus)', Food Chemistry, vol 60, no. 1, 25-28. 
Cunniff, P. 1998, Fruits and fruit products: preparation of fruit sample', in Official Methods of Analysis of $A O A C$ international. ed FE Boland, $A O A C$ International, pp. 2 - 3. USA.

Hakim, EH, Achmad, SA, Juliawaty, LD, Makmur, L, Syah, YM, Aimi, N et al. 2006, 'Prenylated flavonoids and related compounds of the Indonesian Artocarpus (Moraceae)', Journal of Natural Medicines, vol. 60, no. 3, pp. $161-184$.

Hakim, EH, Juliawaty, LD, Syah, YM \& Achm, SA 2005, 'Molecular diversity of Artocarpus champeden (Moraceae): A species endemic to Indonesia', Molecular Diversity, vol. 9, no. 1-3, pp. $149-158$.

Haq, N 2006, Jackfruit, University of Southampton, UK.

Inbaraj, BS \& Sulochana, N 2004, 'Carbonised jackfruit peel as an adsorbent for the removal of Cd(II) from aqueous solution', Bioresource Technology, vol. 94, no. 1, $49-52$.

Janick, J \& Paull, RE 2008, 'The encyclopedia of fruits and nuts', eds. J Janick \& RE Paull, CABI.

Jarrett, FM 1960, 'Studies in Artocarpus and allied genera, IV. A revision of Artocarpus subgenus Pseudojaca', Journal of Arnold Arboretum, vol. 41, no. 1, pp. $73-140$.

Kirk, RS \& Sawyer, R 1991, Pearson's composition and analysis of foods, Longman, New York.

Lim, SB, Chua, CT \& Hasim, OH 1997, 'Isolation of a mannose-binding and IgE- and IgM- reactive lectin from the seeds of Artocarpus integer', Journal of Immunological Methods, vol. 209, no. 2, $177-186$.
Madamba, LSP 2000, 'Crude fibre by the Weende method', in Technical analysis I: Foods and Feeds (Chemistry 131), ed. ME Flavier, Philippines.

Nielsen, SS 2003a, 'Determination of fat content: Soxhlet method', in Food Analysis Laboratory Manual, ed DR Heldman, Kluwer Acadamic / Plenum Publishers, New York.

Nielsen, SS 2003b, 'Kjeldahl nitrogen method', in Food Analysis Laboratory Manual, ed DR Heldman, Kluwer Acadamic / Plenum Publishers, New York.

Nielsen, SS 2003c, 'Phenol-sulphuric acid method for total carbohydrate', in Food Analysis Laboratory Manual, ed DR Heldman, Kluwer Acadamic / Plenum Publishers, New York.

Prahas, D, Kartika, Y, Indraswati, N \& Ismadji, S 2008, 'The use of activated carbon prepared from Jackfruit (Artocarpus heterophyllus) peel waste for methylene blue removal', Journal of Environmental Protection Science, vol. 2, pp. $1-10$.

Ranganna, S 1986, 'Proximate analysis', in Handbook of analysis and quality control for fruit and vegetable products, 2nd edn, Tata McgrawHill Publishing Company Limited, New Delhi.

Subhadrabandhu, S 2001, 'Artocarpus integer Merr', in Under-utilized tropical fruits of Thailand, RAP Publication, Bangkok.

Zabidi, MA \& Aziz, NAA 2009, 'In vitro starch hydrolysis and estimated glyceamic index of bread substituted with different percentages of champedak (Artocarpus integer) seed flour', Food Chemistry, vol. 117, no. 1, 64-68. 